\title{
Structural characterization of the $\mu$-Nitrido Complex $\left\{[\mathrm{Fe}(\mathrm{OEP})]_{2} \mathrm{~N}\right\}$
}

\author{
Ming Li and W. Robert Scheidt \\ Department of Chemistry and Biochemistry, 251 Nieuwland Science Hall, University of Notre \\ Dame, Notre Dame, Indiana 46556 USA
}

\begin{abstract}
The molecular structure of the $\mu$-nitrido dimer, $\mu$-nitrido-bis $(2,3,7,8,12,13,17,18$ octaethylporphyrinato)iron, is reported. The axial Fe-N distances average to 1.657 (11) $\AA$ and the equatorial distances average to 2.005(5) $\AA$. Although not required by symmetry, the two iron centers appear equivalent and are consistent with an assignment of a low-spin state and a formal oxidation state of +3.5 . A comparison of this structure with other nitrido-bridged species is given.
\end{abstract}

\section{Keywords}

iron porphyrin; $\mu$-nitrido dimer; X-ray structure

\section{Introduction}

The recent report in this journal [1] of the synthesis and characterization of the nitrido bridged species $\left\{[\mathrm{Fe}(\mathrm{OEP})]_{2} \mathrm{~N}\right\}[2]$ prompts us to report our synthesis and, more importantly, the X-ray structure determination of molecular $\left\{[\mathrm{Fe}(\mathrm{OEP})]_{2} \mathrm{~N}\right\}$. Binuclear nitrido-bridged species of both porphyrin and phthalocyanine macrocycles have been studied for their possible utilization as catalysts in oxidation reactions [3, 4]. We had originally synthesized $\left\{[\mathrm{Fe}(\mathrm{OEP})]_{2} \mathrm{~N}\right\}$ as part of a program to characterize both the neutral nitrido-bridged species $\left\{[\mathrm{Fe} \text { (porph) }]_{2} \mathrm{~N}\right\}$ and the one electron oxidized relative. This work was part of program to better understand the electronic structure of these species, but we have not been able to obtain crystals of the oxidized OEP species. However, this work has been completed for $\left\{[\mathrm{Fe}(\mathrm{TPP})]_{2} \mathrm{~N}\right\}[5]$ and $\left\{[\mathrm{Fe}(\mathrm{TTP})]_{2} \mathrm{~N}\right\}^{+}[6]$, which have formal oxidation states for the iron centers of +3.5 and +4.0 , respectively. We compare the details of this new structure with those of earlier nitrido bridged species and other binuclear iron species.

Correspondence to: W. Robert Scheidt.

Supporting Information Crystallographic data have been deposited at the Cambridge Crystallographic Data Centre (CCDC) under number CCDC 973366. Copies can be obtained on request, free of charge, via www.ccdc.cam.ac.uk/datarequest/cif or from the Cambridge Crystallographic Data Centre, 12 Union Road, Cambridge CB2 1EZ, UK (fax: +44 1223-336-033 or deposit@ccdc.cam.ac.uk). 


\section{Experimental Section}

\section{General Information}

All manipulations were carried out under argon using a double manifold vacuum line, Schlenkware and cannula techniques. Dichloromethane was distilled over $\mathrm{CaH}_{2}$, and hexanes were distilled over sodium benzophenone. $\mathrm{H}_{2} \mathrm{OEP}$ was purchased from Midcentry Chemical. All other chemicals were used as received from Aldrich or Fisher. [Fe(OEP)Cl] and $\left[\mathrm{Fe}(\mathrm{OEP})\left(\mathrm{N}_{3}\right)\right]$ were synthesized by literature methods $[7,8]$. UV-vis spectra were recorded on a Perkin-Elmer Lambda 19 spectrometer and IR spectra on a Perkin-Elmer model 883 as $\mathrm{KBr}$ pellets. EPR spectra were obtained at $77 \mathrm{~K}$ on a Varian E-12 spectrometer operating at X-band.

\section{Synthesis of $\mu$-Nitrido-bis(octaethylporphyrinato)iron}

$\left\{[\mathrm{Fe}(\mathrm{OEP})]_{2} \mathrm{~N}\right\}$ was prepared by the method of Summerville and Cohen [9]. UV-vis $\left(\mathrm{CH}_{2} \mathrm{Cl}_{2}\right.$ solution)(log $\left.\varepsilon\right): \lambda_{\max }: 368,554,586 \mathrm{~nm}$. IR(KBr): $v(\mathrm{Fe}-\mathrm{N}-\mathrm{Fe}) 931(\mathrm{~s}) \mathrm{cm}^{-1}$. EPR (frozen $\mathrm{CH}_{2} \mathrm{Cl}_{2}, 77 \mathrm{~K}$ ) $\mathrm{g}_{\perp}=2.14, \mathrm{~g}_{\|}=2.00$.

\section{X-Ray Structure Determination}

Crystals of $\left\{[\mathrm{Fe}(\mathrm{OEP})]_{2} \mathrm{~N}\right\}$ suitable to $\mathrm{X}$-ray analysis was obtained by a vapor diffusion of hexanes into a $\mathrm{CH}_{2} \mathrm{Cl}_{2}$ solution of $\left\{[\mathrm{Fe}(\mathrm{OEP})]_{2} \mathrm{~N}\right\}$. X-ray diffraction data were collected on a Nonius FAST area-detector diffractometer with a Mo rotating anode source $(\lambda=$ $0.71073 \AA$ ) at $130 \mathrm{~K}$. Our detailed methods and procedure for small molecular X-ray data collection have been described previously[10]. A modified version [11] of the absorption correction program DIFABS was applied.

The structure was solved by direct methods [13]. Subsequent difference Fourier calculations revealed the positions of the remaining non-hydrogen atoms. All non-hydrogen atoms were refined anisotropically by full-matrix least-squares methods utilizing all data [13]. Hydrogen atoms of the porphyrin ligand were idealized with the standard SHELXL idealization methods. Brief crystal data are listed in Table 1.

\section{Results and Discussion}

The structure of the $\left\{[\mathrm{Fe}(\mathrm{OEP})]_{2} \mathrm{~N}\right\}$ molecule is illustrated in the ORTEP diagrams of Figures 1 and 2. As can be seen in Figure 1, the two porphyrin rings approach each other closely and most, but not all, of the peripheral ethyl groups are towards the outside of the dimeric molecule. There is no required symmetry for the molecule, unlike many related derivatives; thus the $\mathrm{Fe}-\mathrm{N}-\mathrm{Fe}$ angle is not required to be linear and indeed is not quite linear at $175.2(2)^{\circ}$. The two porphyrin planes make a dihedral angle of $7.2^{\circ}$; and neither porphyrin plane is planar as discussed below. The two axial $\mathrm{Fe}-\mathrm{N}$ bonds are both very short at 1.649(4) and 1.665(4) $\AA$, consistent with strong multiple bonds. The average value of the eight equatorial $\mathrm{Fe}-\mathrm{N}_{\mathrm{p}}$ bonds is $2.005 \AA$, consistent with a low-spin state for both iron atoms [14].

Figure 2 provides a top-down view that illustrates the $23.10^{\circ}$ twist angle between the two porphyrin rings of $\left\{[\mathrm{Fe}(\mathrm{OEP})]_{2} \mathrm{~N}\right\}$. The several structural differences between the 
$\left\{[\mathrm{Fe}(\mathrm{OEP})]_{2} \mathrm{~N}\right\}$ and $\left\{[\mathrm{Fe}(\mathrm{TPP})]_{2} \mathrm{~N}\right\}$ systems reflect the differing steric factors in bringing the two porphyrin rings in close proximity. These include differences in the iron atom displacements, the interring separation, and the twist angle. Table 2 displays these structural parameters and available equivalent information for several additional monobridged $\mathrm{Fe}$ (III) and F(IV) porphyrin and phthalocyanine species. The closer approach of the porphyrin rings in the OEP species leads to the very short Fe...Fe distance of $3.311 \AA$, which has also been observed from EXAFS measurements [1], the $0.3 \AA$ difference in the interplanar spacing, and the smaller twist angle in the OEP derivative.

Figures 3 and 4 display averaged values of the bonding parameters in the two independent porphyrin rings of $\left\{[\mathrm{Fe}(\mathrm{OEP})]_{2} \mathrm{~N}\right\}$. As is readily observed from the two diagrams, the structural parameters for the two rings are equivalent to well within the estimated uncertainties. This equivalence between the two rings does not extend to the ring conformations. The two conformations are quite distinct. The conformation of ring 1 (Figure 3 ) is seen to be a combination of ruffing and saddling, whereas the conformation of ring 2 (Figure 4) is seen to be much more that of a simple ruffed core. Reasons for the differences are not clearl; steric factors do not appear to be the cause.

A cell packing diagram in 50\% thermal ellipsoid format and including all hydrogen atom is given in Figure 5. The $\left\{[\mathrm{Fe}(\mathrm{OEP})]_{2} \mathrm{~N}\right\}$ molecules are seen to form a zigzag column along the c-axis with the porphyrin planes approximately parallel to the ab plane. In our experience the inclusion of hexane solvate molecules, especially well-ordered ones, is quite rare. As can be seen in the figure, the six-carbon chains are approximately perpendicular to the pair of porphyrin planes of $\left\{[\mathrm{Fe}(\mathrm{OEP})]_{2} \mathrm{~N}\right\}$. The molecule of interest and the solvate molecule have commensurate dimensions. This feature may in fact be responsible for the good ordering of the $n$-hexane chains.

\section{Supplementary Material}

Refer to Web version on PubMed Central for supplementary material.

\section{Acknowledgments}

We thank the National Institutes of Health for support of this research under Grant GM-38401 to WRS. Funds for the purchase of the FAST area detector diffractometer was provided through NIH Grant RR-06709 to the University of Notre Dame.

\section{References and Notes}

1. Kudrik EV, Albrieux F, Afanasiev P, Sorokin AB. J Porphyrins Phthalocyanines. 2013; 17:791-798.

2. Abbreviations: OEP, dianion of octaethylporphyrin; TPP, dianion of tetraphenylporphyrin; TTP, dianion of tetratolylhporphyrin; porph, dianion of a generalized porphyrin ; Pc, phthalocyanine; EXAFS, extended X-ray absorption spectroscopy.

3. Kudrik EV, Afanasiev P, Alvarez LX, Dubourdeaux P, Clémancey M, Latour JM, Blondin G, Bouchu D, Albrieux F, Nefedov SE, Sorokin AB. Nature Chem. 2012; 4:1024-1029. [PubMed: 23174983]

4. Ercolani C, Jubb J, Pennesi G, Russo U, Trigiante G. Inorg Chem. 1995; 34:2535-2541.

5. Scheidt WR, Summerville DA, Cohen IA. J Am Chem Soc. 1976; 98:6623-6628. 
6. Li M, Shang M, Ehlinger N, Schulz CE, Scheidt WR. Inorg Chem. 2000; 39:580-583. [PubMed: 11229580]

7. Adler AD, Longo FR, Kampas F, Kim J. J Inorg Nucl Chem. 1970; 32:2443-2445.

8. Byers W, Cossham JA, Edwards JO, Gordon AT, Jones JG, Kenny ETP, Mahmond A, McKnight J, Sweigart DA, Tondreau GA, Wright T. Inorg Chem. 1986; 25:4767-4774.

9. Summerville DA, Cohen IA. J Am Chem Soc. 1976; 98:1747-1752. [PubMed: 3536]

10. Scheidt WR, Turowska-Tyrk I. Inorg Chem. 1994; 33:1314-1318.

11. The process is based on an adaptation of the DIFABS [12] logic to area detector geometry by Karaulov: Karaulov, A. I.; School of Chemistry and Applied Chemistry, University of Wales, College of Cardiff, Cardiff CF1 3TB, UK, personal communication.

12. Walker NP, Stuart D. Acta Crystallogr. 1983; A39:158-166.

13. Sheldrick GM. Acta Crystallogr. 2008; A64:112-122.

14. Scheidt WR, Reed CA. Chem Rev. 1981; 81:543-555.

15. Kienast A, Homborg HZ. Anorg Allg Chem. 1998; 624:233-238.

16. Moubaraki B, Benlian D, Baldy A, Pierrot M. Acta Cryst C. 1989; 45:393-394.

17. Goedken VL, Deakin MD, Bottomley LA. J Chem Soc, Chem Commun. 1982:607-608.

18. Kienast A, Galich L, Murray KS, Moubaraki B, Lazarev G, Cashion J, Homborg H. J Porphyrins Phthalocaynines. 1997; 1:141-157.

19. Cheng B, Hobbs JD, Debrunner PG, Erlebacher J, Shelnutt JA, Scheidt WR. Inorg Chem. 1995; 34:102-110. 


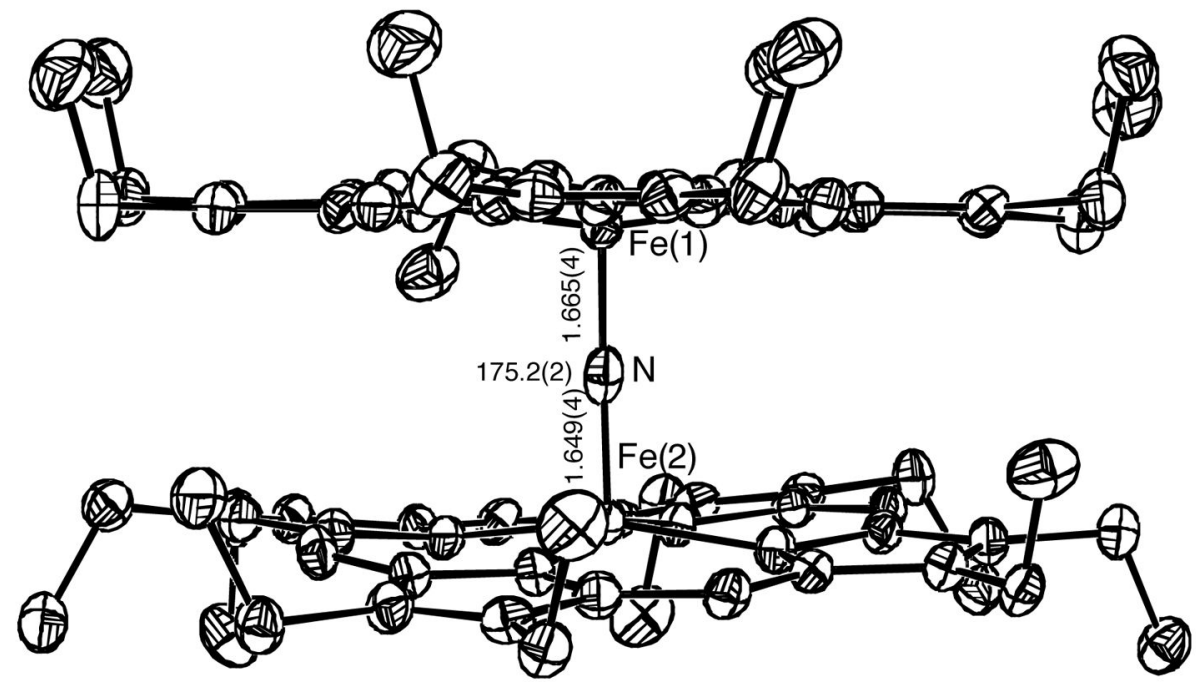

Figure 1.

Side-on ORTEP diagram of $\left\{[\mathrm{Fe}(\mathrm{OEP})]_{2} \mathrm{~N}\right\} .50 \%$ probability ellipsoids are shown. Hydrogen atoms eliminated for clarity. 


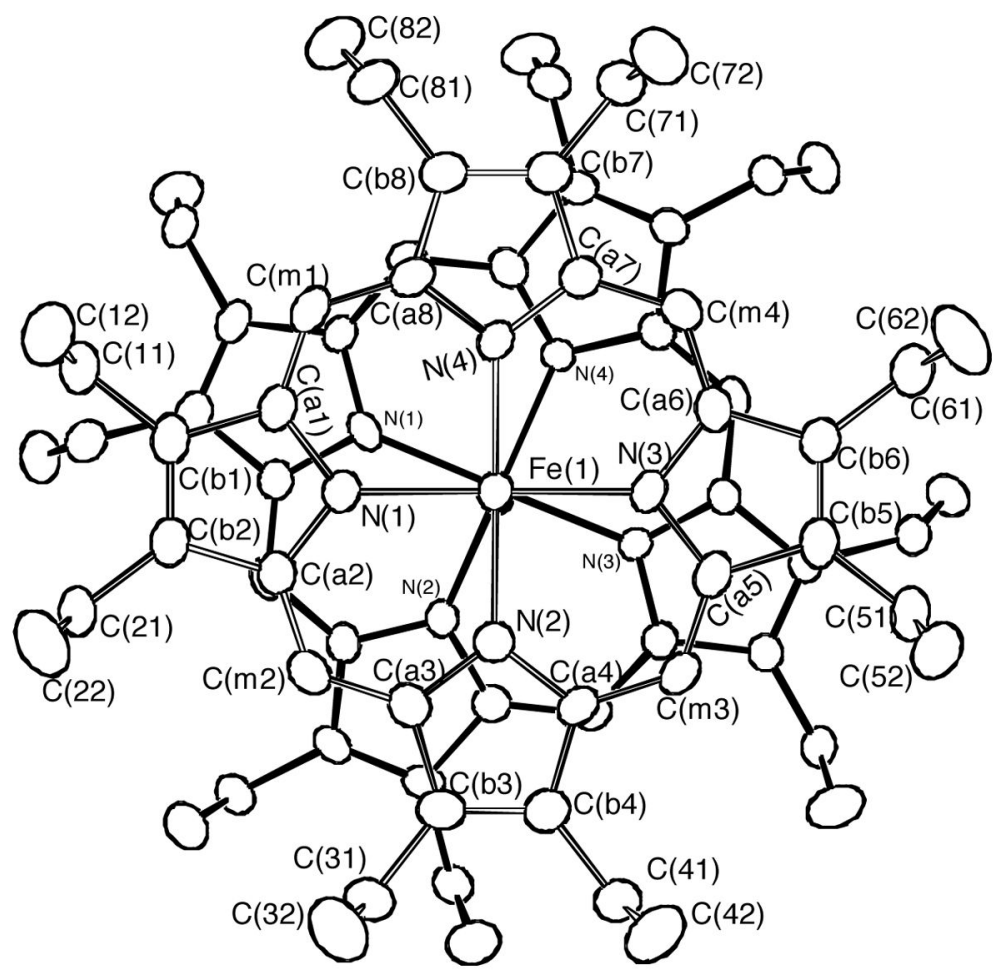

Figure 2.

Top-down view of $\left\{[\mathrm{Fe}(\mathrm{OEP})]_{2} \mathrm{~N}\right\} .50 \%$ probability ellipsoids are shown. Hydrogen atoms eliminated for clarity. The atom labeling scheme is also shown. 


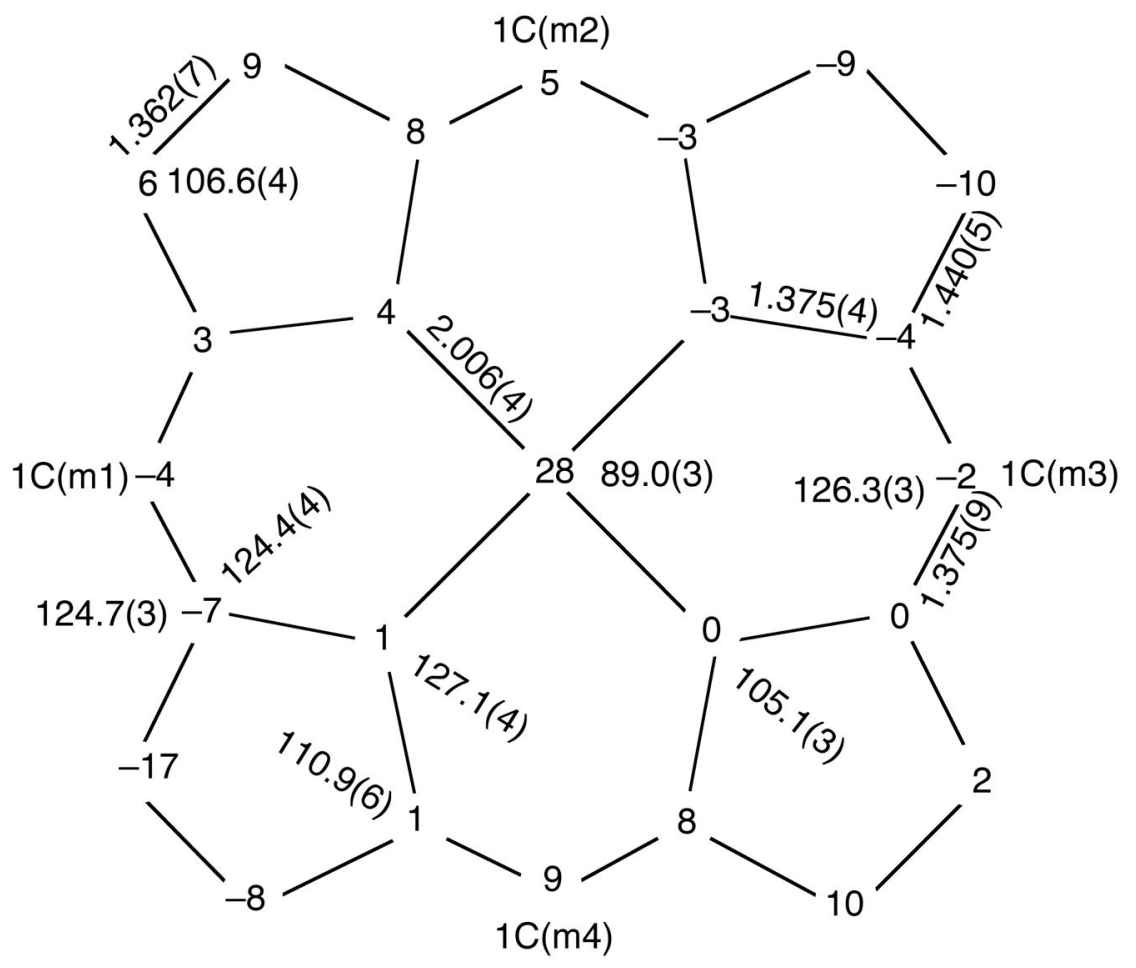

Figure 3.

Formal diagram of the porphinato core of ring 1 of $\left\{[\mathrm{Fe}(\mathrm{OEP})]_{2} \mathrm{~N}\right\}$ displaying perpendicular displacements, in units of $0.01 \AA$, of the core atoms from the 24 -atom mean plane. Positive values of displacements are towards the bridging nitride. Averaged values of the chemically unique bond distances (in $\AA$ ) and angles (in deg.) are shown. 


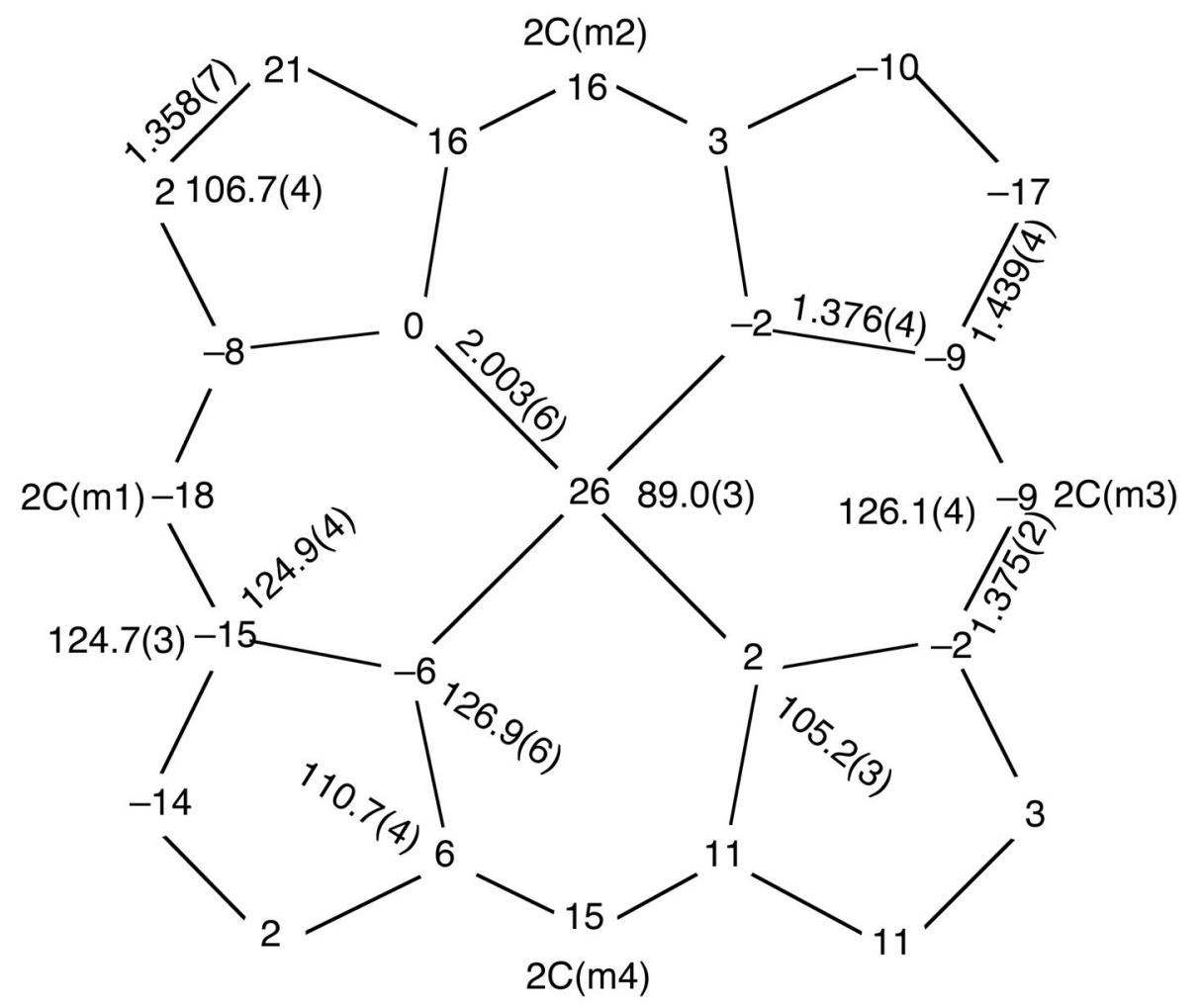

Figure 4.

Formal diagram of the porphinato core of ring 1 of $\left\{[\mathrm{Fe}(\mathrm{OEP})]_{2} \mathrm{~N}\right\}$ displaying perpendicular displacements, in units of $0.01 \AA$, of the core atoms from the 24 -atom mean plane. Positive values of displacements are towards the bridging nitride. Averaged values of the chemically unique bond distances (in $\AA$ ) and angles (in deg.) are shown. 


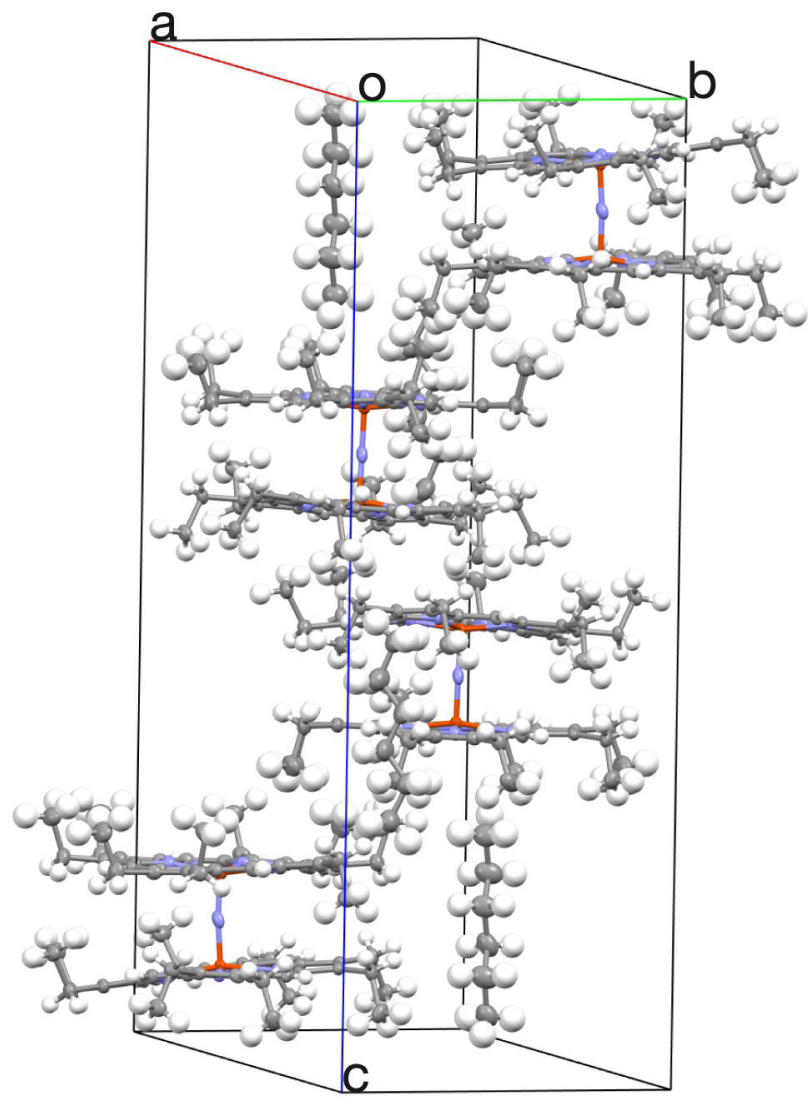

Figure 5.

Diagram illustrating the packing of the $\left\{[\mathrm{Fe}(\mathrm{OEP})]_{2} \mathrm{~N}\right\}$ molecules and the $n$-hexane solvates in the unit cell (50\% probabilities shown). Cell axes are labelled. 


\section{Table 1}

Crystallographic details for $\left\{[\mathrm{Fe}(\mathrm{OEP})]_{2} \mathrm{~N}\right\}$.

\begin{tabular}{lc}
\hline formula & $\mathrm{C}_{72} \mathrm{H}_{88} \mathrm{Fe}_{2} \mathrm{~N}_{9} \cdot \mathrm{C}_{6} \mathrm{H}_{14}$ \\
$\mathrm{FW}$, amu & 1277.39 \\
$a, \AA$ & $13.9256(19)$ \\
$b, \AA$ & $13.8434(14)$ \\
$c, \AA$ & $35.200(2)$ \\
$\beta$, deg & $96.614(10)$ \\
$V, \AA^{3}$ & $6740.6(12)$ \\
space group & $P 2_{1} / n$ \\
$Z$ & 4 \\
$\mathrm{D}_{\mathrm{c}}$, g/cm & \\
$\mathrm{F}(000)$ & 1.259 \\
$\mu, \mathrm{mm}^{-1}$ & 2740 \\
crystal dimensions, mm & 0.482 \\
radiation & $0.30 \times 0.17 \times 0.06$ \\
goodness-of-fit (based on $\left.F^{2}\right)$ & $M o K a, \lambda=0.71073 \AA$ \\
final $R$ indices [I $>2 \sigma(\mathrm{I})]$ & 1.031 \\
final $R$ indices (all data) & $R_{1}=0.0664, w R_{2}=0.1656$ \\
\hline
\end{tabular}


